\title{
The Architectonics of Corporeal and Textual Selves: From Durga via Banalata Sen to the Virtual Indian Woman
}

\author{
Ramona L. CECIU *
}

\begin{abstract}
This paper traces a line of thought in representations of the Indian woman across literary and visual genres, from the so-called traditional to modern conceptualizations. It discusses the manner in which the woman was variously represented in line with the cultural architectonics that assigned her particular identities - from the woman as goddess/mother, located in the private space to the woman as modern entity located within the public (urban) domain, as well as the outcast woman and the virtual woman. I attempt an inter-textual reading of the literary/visual corporeal and textual selves, by drawing mainly on Bakhtin's concepts of "answerability" and "unfinalizable selves." I emphasize these concepts with regard to the dialogue between artists and authors, and between the work of art and its readers.
\end{abstract}

Keywords: woman, self, literature, painting, film, Bakhtin, Indian culture

\section{Izvleček}

Ta članek sledi poti mišljenja v reprezentacijah indijske ženske skozi literarne in vizualne žanre, od tako imenovanih tradicionalnih do modernih konceptualizacij. Predstavlja način, na katerega je bila »ženska« različno predstavljena v skladu s kulturnimi aspekti, ki ji dodeljujejo posebne identitete — od »ženske« kot boginje/matere, ki se nahaja v zasebnem prostoru, do ženske kot sodobnega subjekta, ki se nahaja znotraj javne (mestne) domene, kot tudi izobčene ženske in virtualne ženske. Raziskuje tudi medtekstualno branje literarnih/vizualnih telesnih in tekstualnih jazov zasnovanih predvsem na Bahtinovih konceptih o »odgovornosti« in »neizoblikovanosti sebe«. Prispevek se osredotoča na te koncepte $\mathrm{v}$ zvezi $\mathrm{z}$ dialogom med umetnikom in avtorjem ter med umetnino in njenimi bralci.

Ključne besede: ženska, sebstvo, literatura, slikarstvo, film, Bakhtin, indijska kultura

\footnotetext{
* Ramona L. Ceciu, PhD Candidate, Comparative Literature, Jadavpur University, Kolkata, India. ramonaelcy@yahoo.com
} 


\section{Introduction}

This paper aims to engage with the idea of the corporeal self in the various representations of women throughout India's cultural history. I intend to employ Bakhtin's concept of "answerability" to elucidate the dialogue (and dialogism) I believe to exist between the literary and visual representations of Indian woman. Primarily I will be looking at paintings, but I also intend to draw on film to illustrate my point. Shabari and Durga, for instance, both represent characters from the mythological epic the Ramayana and are frequent figures in paintings; Charulata is both a literary and a film character, she has also inspired painters; Banalata Sen is a female protagonist in an eponymous poem and an anthology of poems; she is a concept of woman, a painted figure as well as a unique collection in the emotional history of a region captured by the sensitivity of a unique poet, Jibanananda Das. Through these female characters, I wish to trace a line of thought in Indian culture extending from traditional notions of woman(hood) to modern contemporary perspectives - from the woman as goddess and mother, located in the private (and mythological) space via the woman split along the traditional/modern axis to the "modern" woman located within the public (urban) domain, as well as the outcast woman and, finally the virtual woman.

This investigation raises questions about the manner in which synchronic and diachronic individual histories intersect with larger histories at work in an ongoing process of permutations in textual and cultural architectonics. In this context, the literary and visual text can be viewed as an embodiment of different histories and identities stitched together into a Frankensteinean body, an unfinalizable self, always in search of a potentially complete identity within the perception field of the reader/viewer. I want to look at each text as an artistic "embodiment" of distinct voices and histories. These histories take shape in distinct media and intertexts, in specific forms visible in some of the post-independence and contemporary paintings, emblematically in the Bikash Bhattacharjee's chef-d'oeuvre, which is largely composed of portrayals of women. I shall keep in mind Mikhail Bakhtin's concepts of art, self and "answerability," and view each text as a being in which multiple (textual) selves and histories circulate and communicate messages that all contribute to the relative construction of a whole textual being and a particular architectonics of self. I shall place it in interaction with the surrounding medium in a process of achieving a unity of meaning and "answerability" both in relation to the piece of art and one's own self. The last part of the paper will carry the 
discussions about womanhood into the virtual world, relating it to identity shifts and "answerability" in the context of encounters in the virtual time/space.

\section{Bakhtin-A Few Concepts and Illustrations}

Metaphors, symbols, poetic sensitivities, artistic associations, whether manifested in simple or complex idioms, are devices without which neither a literary nor visual text can bestow pleasure on the mental eye and achieve a degree of greatness, for they are no mere ornaments of the artistic body, but an integral part of it. Any text, literary or visual, abounds in meanings on various textual levels and any recipient gets as many meanings as they can, in accordance with their emotional response to the artistic creation and depth of investigation. Identities and meanings in a given text are always constructed through the interactions and intersections with other identities, such as those of the author, the recipient, but equally the circumstances of the acts of creation, circulation and reading of the artistic text. Mikhail Bakhtin defined the "chronotope" as "the intrinsic connectedness of temporal and spatial relationships that are artistically expressed in literature," but I would note that this concept can not only be applied to other art forms, such as painting and film viewed as artistic narrative texts, but may also be extended beyond the time-space axis. The "chronotope" of a given literary/visual Text artistically expressing the intrinsic time-space matrix at the moment of its creation may be combined with the time-space matrix at the moment of its exhibition and reception, as well as with other works existing independently of, yet (in)directly, referring to it. All these can be seen as interconnected in a real (lived) chronotope, which may be defined as a kind of metachronotope. This implies a "dialogic" encounter between the text and its context at different points in the course of a given work's existence. It also suggests "an excess of seeing" on the part of the reader's/viewer's experience of reading the text. Dialogism, as Esther Peeren has remarked, puts forward a relation of "simultaneity able to accommodate difference and distance as well as similarity," while "dialogic intersubjectivity marks dissonance and distance rather than harmony and closeness; it is not about recognizing the other as the same, but about respecting the other as different and taking responsibility for this difference" (Peeren 2008, 14-17). In this light, the concept of "dialogism" tends towards a distrust of all fixed systems in what is a deconstructive stance, where attributing a single identity or a set of fixed meanings to a text is an impossible task, constantly undermined by the very 
fluidity of meanings. The concern here is with the other beyond language, with an essential openness of the text. In "Author and Hero in Aesthetic Activity" (1924), Bakhtin stated: "My own unity, for myself, is one that confronts me eternally as a unity-yet-to-be; it is a unity that is both given and not given to me; [...it is] not the unity of my already being, but the unity of my not-yet-being"- a "value to be achieved" (126). All creations abound in variable meanings. Like one's individual self, texts too are always in the process of "achieving unity," or in Bakhtin's terminology, the unity is determined by "polyphony," "polyglossia" and "heteroglossia" - the dominance of context over text. Bakhtin looks at details, individual utterances, inner-texts and identities in order to understand the Text in its "tentative wholeness" and "consummation," placing the "intertexts" of a Text in their social and historical perspective. For Bakhtin perception is an act of "authoring" or creating a text, while making a distinction between all cognitive levels of awareness and situated awareness experienced by each individual according to the uniqueness of his location in both time and space. He stresses that "aesthetic contemplation and ethical action cannot abstract from the concrete uniqueness of the place in being that is occupied by the subiectum of ethical action as well as by the subiectum of artistic contemplation" $(1924,24)$. Awareness has the potential to lead to "answerability" to art, to a response leading to ethical action, then further to active social-cognitive transformations within the "architectonics" of the cultural psyche.

A good example that lends itself to a Bakhtian analysis combined with the notion of woman in Indian history is that of the contemporary Bengali painter Bikash Bhattacharjee. ${ }^{1}$ As Manasij Majumder has rightly noted, Bikash Bhattacharjee dismissed both Rabindranath Tagore's and the Bengal School of painting, developing instead his own individual world of imagery: "he had a fierce individual angle of perceiving and interpreting contemporary reality." The men and women featuring in his imagery "are each an individual, each with a welletched subjectivity of his/her own, even though their class character is obvious in every detail of the forms and objects evoked with every care for their realistic representation" (Majumder 2007, 68). The painter developed his own "idiom of realism" and admitted that he was "influenced by the cinema" and "inspired by film shots, their composition within a frame," especially when it came to foreign films of the 1950s and 60s, for which the foremost Indian film director Satyajit

\footnotetext{
${ }^{1}$ All paintings where only the title is mentioned belong to Bikash Bhattacharjee. For other images involved in the critical analysis, the name of the artist is mentioned first, followed by the painting title.
} 
Ray had great respect. In "Artists Today" Bikash explained: "I think of the subject first, and my reaction to it. I make notes on it. A few months later I work on the painting" (Majumder 2007, 95-136; 107). Woman appears to be central to his work and seems to be the binding thread of all his thematic representations. This could be directly linked to the marked social and cultural struggle of the period spanning the 1940s and 1960s, in which notions of masculinity and femininity were being rigorously contested and defined along the axis of "tradition" and "modernity." As I will show, it is characteristic of his female portrayals that while standing for matriarchal power they are rendered speechless. His mastery as an artist is embedded precisely in his rendition of these aspects of muteness in their overlap with insidious forms of violence, each canvas representing an "unconsummated" self.

Reading in parallel Bikash's life and his works, one can decipher from many of his paintings a history of emotions and traumas as experienced by an individual self who is an exponent of many other selves with similar experiences. Certainly, it is possible to explore his paintings from the perspective of the metachronotope they inhabit. Some, for example, reflect the adversity his mother had to face as a widow in a society that prescribed widowhood along a strict set of rules. Trauma assumes an interesting form in a 1973 painting of what seems to be an enlarged view of the shutters of a house, nailed into a fixed position, against which stands an Onlooker (Oil, 1973, Fig. 1) represented by a woman, more precisely her head, the face is monstrously disfigured, one eye covered by hair while the other, the potent left eye, staring back at us with resentment.

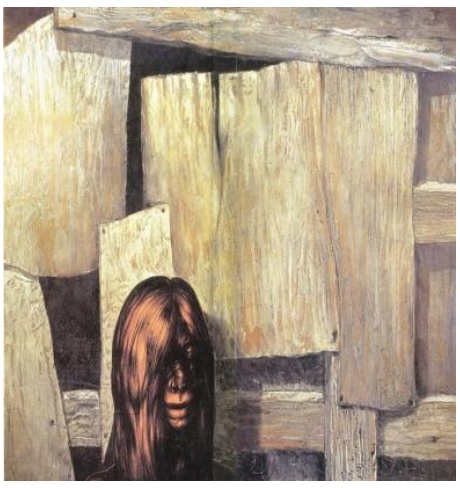

Fig. 1: Onlooker, 1973

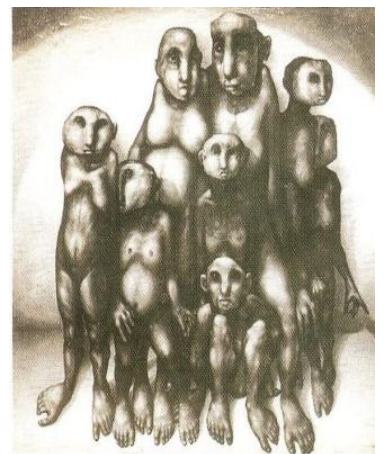

Fig. 2: Golden Masked Family 
Another half-stare features in the painting Totem (Oil, 1971, Fig. 4), where a nude woman, sporting a young body with an old wrinkled face, stands at the base of a totemic living rod. On her shoulders she is supporting a man with long fair hair arms and the legs of a beast, and a doll hanging upside down around his neck. One side of the woman's bosom is covered by one of the legs of the apish male figure and the other by one of the three candles placed in the forefront of the painting, while her face is half covered jointly by the beast's hand and darkness. The doll that carries distinct overtones of Bikash's Doll series acts as a startling counterpoint to the overall image of the totem.

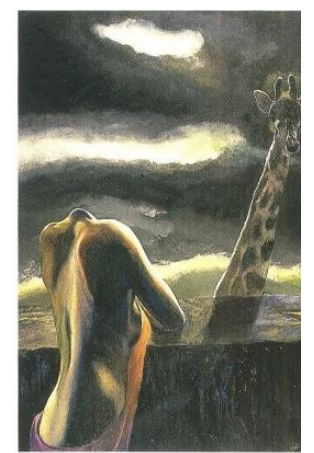

Fig. 3: Onlooker, 1997

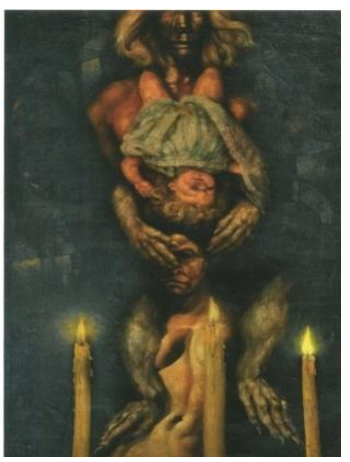

Fig. 4: Totem, 1971

The view of the shutters and woman in Fig. 1 can be seen as a metaphor of the human mind which plays, within its limits, with the contents of its reservoir of mental objects and lacks: namely, the three shutters obstruct the light passage into the house and one can perceive through the gaps the utter darkness within, standing possibly for the unknown and one's inner insecurities and fears. What happens if we relate this potent image to the painting representing masked figures in The Golden Masked Family (1968, Fig. 2) and replace the masked heads with the image of the shutters? The suggestion of numerous blindfolded minds as objects of critique and subjects of trapped identities or frustrations seems powerful indeed.

In another painting entitled Onlooker (Oil, 1997, Fig. 3), we see the naked back of a woman, represented as a headless human trunk and superficially clad in a sari without a blouse, standing by a ledge and stared at by a giraffe. No doubt, this is yet another strong depiction of a gaze whereby another being stares at a young woman with no eyes to return the gaze, and by implication no mind to assert her subjecthood. 


\section{Woman as Saint, Mother, Lover and Unfinalizable Self}

The epics of the Ramayana and the Mahabharata are two major texts that have provided, throughout Indian cultural history, models of traditional concepts of womanhood and female archetypes. As history, mythology and philosophy overlapped, the epics touched on many different aspects of life related to one's birth, death as well as the beyond, encompassing the spiritual being as well as the material self of a civilization. What is especially intriguing is that throughout the ages these two great epics have registered many alterations by way of adjustment to different communities and their identity demands. They also engaged in distinct dialogic patterns encompassing innumerable selves, thereby illustrating the notion of the "unfinalizable self," as well as that of the "answerability" and the architectonics of both individual communities and artistic texts. For instance, some characters' names in Kamban's "Ramayana" were changed phonetically to sound like Tamil names-Lakshmana to Ilakkuvan, Vibishna to Vitanan, Ahalya to Alikai etc., thus expressing intersections and dialogues between literature, myths and people's identities (Varadarajan 1988). Women characters in these mythological works served as inspiration, and bench mark, for the traditional rendition of woman as saint, goddess, mother etc. Practically all modern Indian artists from Raja Ravi Varma (e.g. Draupadi, Lakshmi, Shakuntala) to Jamini Roy (e.g. Three Pujarins, Mother and Child series) to more contemporary representations, as for instance in the works of Bikash Bhatacharjee (Shabari, Mother Teresa, Durga series paintings), have drawn on the imagistic and conceptual reservoir of the two ancient Indian epics.

The preponderant duality of woman as goddess is suggested, in an interesting way, in Bikash's painting entitled Durga (Oil, 1989, Fig. 5), based on the motif of the goddess Durga. The murti (idol) of the divinity is a symbol of the protective mother/deity, but the woman, this time capable of returning the gaze, and portrayed with a third eye like Shiva, is standing in front of the goddess' murti, while looking at us with what appears to be a mixture of sadness and contempt. What does her intense gaze signify? Is she looking at society at large and its patriarchal institutions that assign to her as a woman a particular role in the sociocultural milieu or, is she perhaps critically engaging, with her gaze, the passivity perceived in other women to stand up against the role designated for women? Is her contempt directed towards herself, the other or towards society at large? 


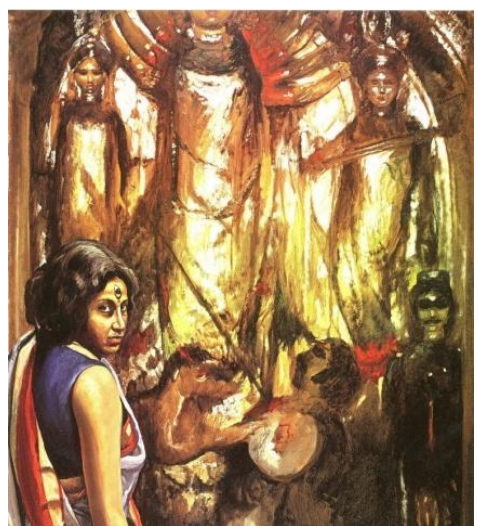

Fig. 5: Durga: Deity/Woman

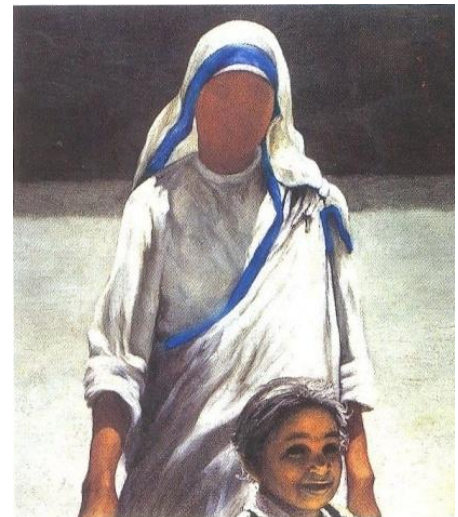

Fig. 6: Mother III, 1981

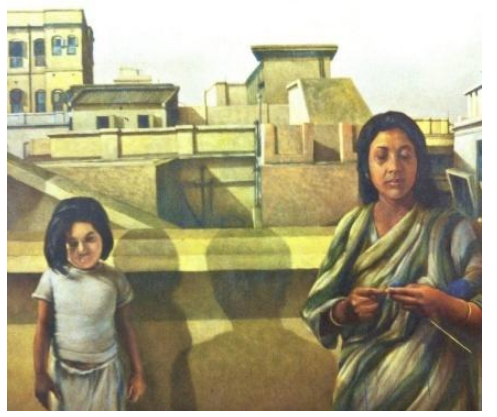

Fig. 7: She in Knitting

The woman as mother appears in Bikash's painting entitled She in Knitting (Oil, 1980, Fig. 7) - where the artist's shade stands for his signature on the one hand and on the other hand for the "mark" of patriarchy on both social and private spaces - as well as some exposés of Mother Teresa (Fig. 6). The latter might usefully be compared to Subrata Gangopadhyay's painting (Fig. 9) and M. F. Husain's peculiar renderings of the idea of motherhood through the images of "Mother Teresa" (Fig. 10), whose face or body is not always clearly visible, but rather suggested through the arrangement of her blue-bordered sari. 


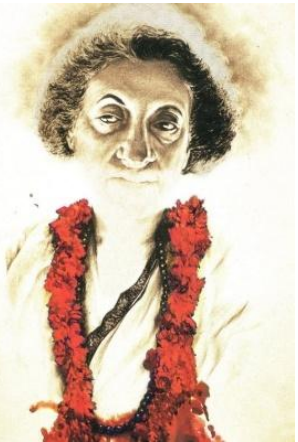

Fig. 8: Martyr

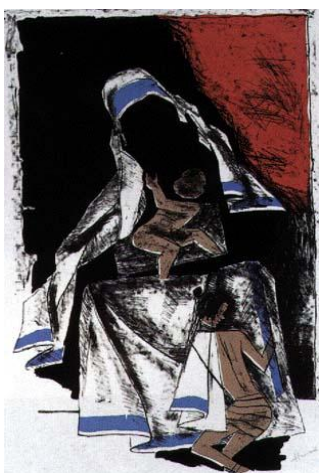

Fig. 10: Husain, Mother Teresa

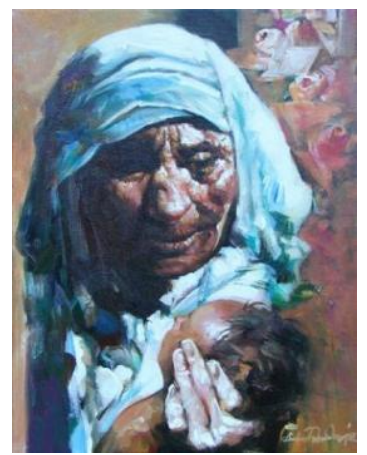

Fig. 9: Gangopadhyay, Mother

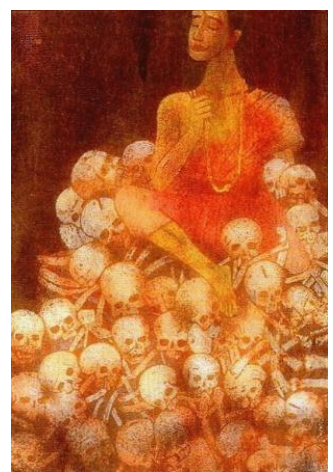

Fig. 11: Pyne, His Dream

Like Gangopadhyay and Husain, Bikash allotted Mother Teresa a space where her different selves and identities seem to engage dialogically with his own artistic self as well as the many voices of various histories, as if he is set on settling the terms of defining her persona. His portrayal of the woman as a public figure found its most controversial form in the depiction of Indira Gandhi in a canvas titled Martyr (Fig. 8) painted after her assassination.

The traditional/modern woman dichotomy, as well as the overlap between the two, could be decrypted from Bikash's painting titled Antique Seller (Oil, 1968, Fig. 12), where the female Siamese twins have one body (the overlap), two almost identical heads and four hands (the dichotomy), while being guarded by some ethereal male figures. The women's eyes and facial features, expressing resignation, have contours similar to the holy women depicted in the tradition of Christian Western paintings. These portrayals, like many others in his repertoire, are suggestive of Bikash's experience as a fatherless child. He witnessed the hardship his mother faced in a society that had always allotted widows a particular place in the social set-up. The harshness of his mother's life and the pulse of 
reality are thus visually recorded and made a part of the painter's artistic signature. The reality suggested in this 1968 canvas, however, is transformed into a stark new vision of a latter-day painting, the Antique Seller (1976, Fig. 13).

The issues of identity seem to have resulted in death, as suggested by the group of decapitated heads, or rather their skulls. Identity itself-along with the struggles for an identity as a living process, be it social, national, gender or any other-is rendered futile in the long run, as individual selfhood and its embodiments are nothing but a Baudelairean "transitoires, fugitives et contingents." Both paintings depict a single human trunk, be it in the full two-headed figure or in the dead partitioned corpse with a number of human skulls scattered around it as in a surrealist dream from Dali. This evokes the unity of the human existential drama, of selfhood as an entity wherein countless versions of self diverge at the level of appearance, but ultimately converge in their essence. The second Antique Seller (1976) begs comparison with Ganesh Pyne's His Dream (Fig. 11) of the Mahabharata series, where "the dreamer" sits on a mound of skulls. This suggests that the dreamer, presumably a "he," has reached a moment of understanding or acceptance of the worldly condition of violence, destruction and futility, which allows him to enter a new level of awareness. If in Bikash's painting that moment of understanding seems to have passed by without being "consummated," the dreamer seems to be more on top of things.

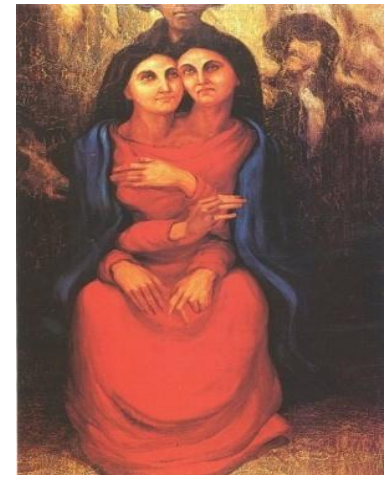

Fig. 12: Antique Seller 1968

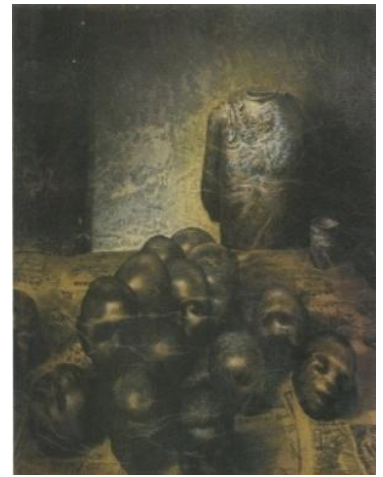

Fig. 13: Antique Seller 1976

The duality of the Antique Seller (1968) actually splits up in Two Sisters (Oil, 1982, Fig. 14), where there are two identities in two corporeal selves; here the line between the notions of "decency" and "indecency" according to Indian culture is 
very fine - the body posture and the apparent interiors of a household contrast with the striking make-up and tempting looks (Majumder 2007, 163).

Tagore's novel Dui Bon (Two Sisters, 1933) springs to mind as an obvious literary cross-reference with which various micro- and macro-histories can be seen to - (un)intentionally-interact and intertwine. The comparison is apt, since Tagore portrays the distinct identities of Dui Bon precisely in the context of the emergence of a "new woman," with all the attendant tensions existing between prācina (traditional woman) and $\bar{a} d h u n \bar{a}$ (modern woman).

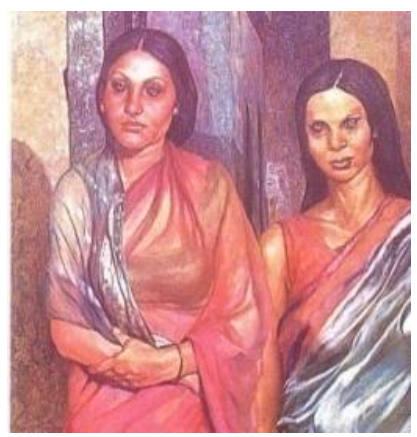

Fig. 14: Two sisters

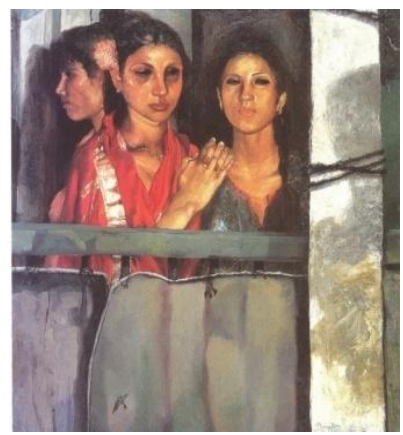

Fig. 15: Juthika, Kamala ...

The issue of forbidden relationships, where conflicting selves struggle to negotiate personal desires with social and ethical duties, surfaces in a relationshiptriangle, where the man eternally needs beside him a submissive (traditional) woman care-taker, but at the same time desires a (modern) woman-lover, since the chances of finding the two aspects in one body seem to be unrealistic. Dui Bon (Two Sisters) is closely related in theme to Tagore's Nastanirh (The Broken Nest, 1903) - considered to be inspired by the real life relation between Tagore and his sister-in-law Kadambari Devi - only that in this story the triangle is formed by one woman (Charulata) and two men. Charulata, immortalized by Satyajit Ray in his beautiful filmic exposé, is representative of a modern woman fully conscious of her individual needs, but like a bird in a cage she is trapped in an unsatisfactory marriage that takes little cognizance of her individuality as a woman nor of her need for an intelligent and sensible relationship with her older husband. Thus she takes refuge in books and music. In her search for inner equilibrium against the conflicting desires and disoriented selves, she finds herself looking for herself within a woman of the past, as she explores the library to recover "Bankim, Bankim, Bankim.” Bankim Chandra Chatterjee, commonly named Bankim, is a 
$19^{\text {th }}$-century Bengali writer famous for his depiction of traditional women characters and his essay on "The Old and The New Woman" (Prācinā ebong Nabinā).

Thus, throughout the film Charulata (played by Madhabi Mukherjee, Fig. 17) quite literally swings to and fro between the two poles along the prācinā (old and traditional) and nabinā (new and modern) axis, both residing in an "unfinalizable self" defined by a continuous search for a unity of her-self and for freedom within the boundaries of the andarmahal (inner quarters). Ray's portrayal of Charulata inspired some representations in painting too, a good example being Bikash's "Charulata" (Fig. 6). The golden background of "Charulata" suggests hope for the future, while the blurred eyes and the ambiguous space in which her swing is suspended create a contrast by suggesting a lack of vision and confusion.

Another artistic rendering of Charulata's confusion and duality is visible in Sudip Roy's series of paintings on this character. In Charulata (2004, Fig. 18) and Charulata White (2004, Fig. 19) of S. Roy both female figures are facing away with their backs turned towards us, but in the opposite direction. The boundaries between the two selves and the two worlds (old and new) as well as the outsideinside dimensions of the self become startlingly visible when Charu explores the outside world to which she has only limited access through the opera glasses (Fig. 17, film still).

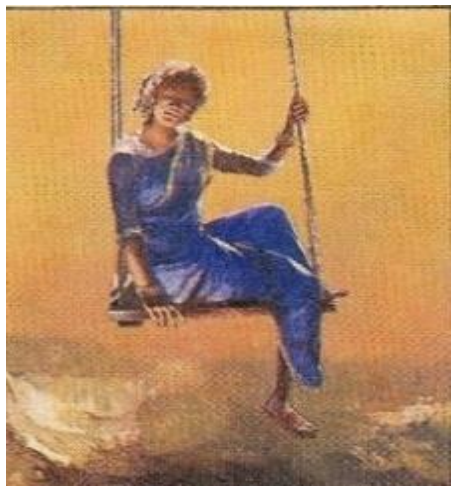

Fig. 16: Bikash's Charulata

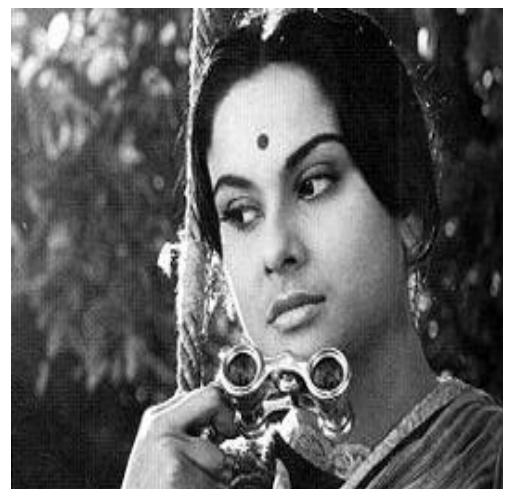

Fig. 17: Ray’s Charulata 


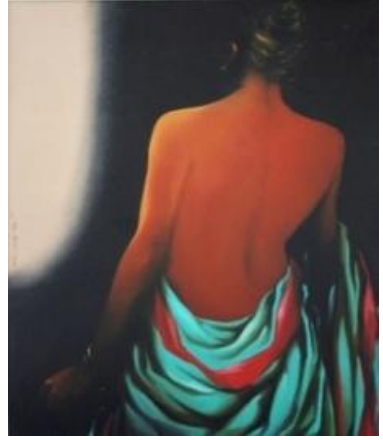

Fig. 18: Roy, Charulata

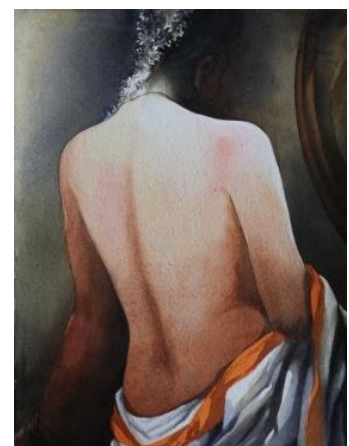

Fig. 19: Roy, Charulata White

The idea of entrapment characterizes many portrayals of women in Bikash's oeuvre (A Portrait, Juthika, Kamala in Fig. 15 above, etc.). In addition Bikash portrays another type of woman who occupies a marginal social position, as an outcast, sometimes a homeless or a disabled woman. ${ }^{2}$ While society contains and sometimes accepts these women, who act as a reminder of the possibilities of "fall" to women in "reputable" social position, it very rarely integrates them into the social fold. The painting Juthika, Kamala... (Fig. 15) presents the case of the woman's body as an exhibit. The strong, almost garish colors gesture towards her being on display for consumption, pointing towards what for some might be an undesirable extreme. Juthika probably represents a character out of Premendra Mitra's eponymous story, a poor woman of dubious reputation, who has stepped out of the "respectability" scheme, forced to do so by unfortunate circumstances. Distinct from Jaya and Bijoya (1990, Fig. 20), who may exemplify middle-class modern Bengali women, Mitra's Juthika does not belong to any class as such. Even so, her attempt to introduce herself as a teacher suggests her desperate desire for a respectable identity. Having escaped the village, she took refuge in the city, a space of supposed freedom and anonymity but also of limitation and erasure of identity. Considering the chronotopic nexus of the story-grounded within the metachronotope of the "lived reality"-it is clear that, regardless of the reasons behind social ostracism, a "fallen" woman can never cross back into the realm of respectability: Juthika was to be regarded as an object of social contempt and of the masculine gaze that both desired and despised her.

Unlike Juthika, Kamala, the character of Tagore's The Tale of a Muslim Woman, is rescued and her dignity reinstated into a different chronotopic pattern. This is enabled through a kind of "identity surgery," a sine qua non for her esteem

\footnotetext{
${ }^{2}$ See Anita Ghai's work ("Disabled Women...") on the topic.
} 
restoration. She was a beautiful orphaned girl living in her Brahmin uncle's house. Her aunt saw her as inauspiciousand evil because, in Tagore's words, "to have a beautiful daughter in one's house was a veritable curse" $(1941,49)$. Thus, Kamala was hastily married off to a womanizer, the younger son of Parmanand Seth, a Bhojpuri pahelwan (wrestler). Attacked by robbers on her wedding day, she was saved by a respected Muslim by the name of Habir Khan, who took her to Rajputni's palace and allowed her to live like a Hindu. She fell in love with Habir's son, Karim, and converted to Islam, getting a new name for herself (Meherjan). Later she became a "fearless woman" who helped other women who found themselves in a similar situation.

Comparable to Juthika, the image of muddled identities materializes in Bikash's Durga in the Morning (1990, Fig. 21). In this painting Durga, the mother-deity type of woman is portrayed as a lover. The room with a small latticed window possibly evokes a critique of certain limitations imposed by Indian culture on a woman, seen emblematically as either a mother or a lover. Interestingly, the fact that Juthika could rent a room and have her own space, even if only as temporary property, is particularly significant in view of the narrative in which she defends this space as her last resort at maintaining a position within society, however low that position might be. If she were to lose the rented room and be thrown into the streets, there would be no way for her to get back into the social structure, since homelessness for the Indian woman signifies a social death and a verdict of forever lurking in the interstitial space (a lived chronotope) between marginality and non-existence.

Thus it is clear that in the stories of Juthika and Kamala, the time-space nexus directly contributed to the construction of identities both as "I-for-myself" and "Ifor-the-other," that is, both in terms of self-identities as self-narrations and selfidentities as others' narrations. Since this is an ongoing process, the concept of "unfinalizable self" is pregnant with innumerable possibilities of becoming, among which the total exclusion from the social scheme seems to be the most undesirable. One of the most moving portrayals of this type of outcaste woman that seems to allude to everything from terrible suffering, to hunger, destitution, homelessness, possibly even delusion, is Abstraction (Ink \& Pastel, 1962, Fig. 22). In this painting an old, half-clad woman with a painfully disfigured body, probably out in the streets somewhere, is holding a mirror in her bony wrinkled hand for herself to look at. 


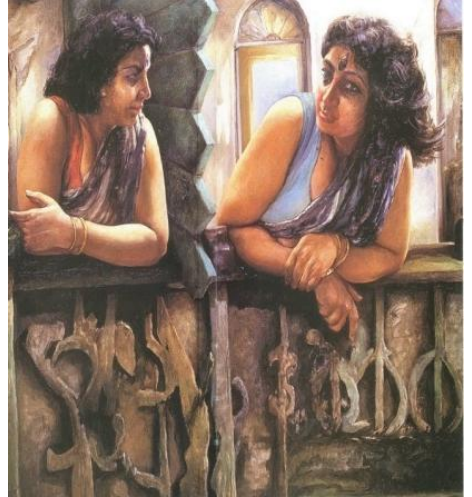

Fig. 20: Jaya, Bijaya...

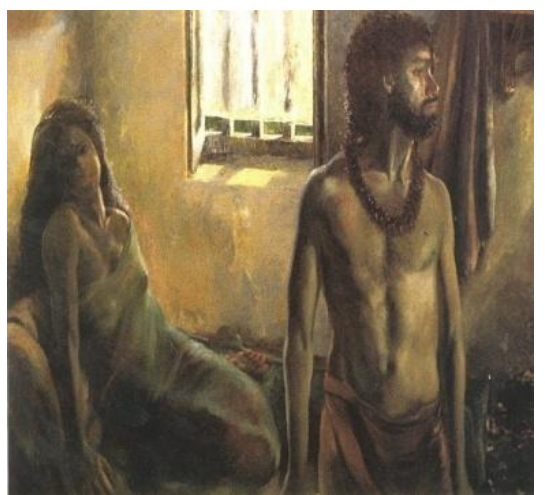

Fig. 21. Durga in the Morning

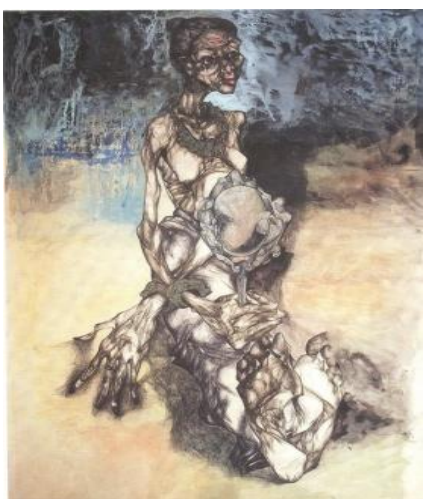

Fig. 22: Abstraction

The gloomy indistinct background suggests the larger dark history of homelessness and poverty. Countering her condition, ornaments-bangles, earrings and necklace - adorn her almost bare body. Unlike the evil queen of the Western tale, she probably does not inquire "Who's the fairest of them all?" Instead she could be asking: "What is my place in this world?" or "Who may give me a better position in the world?" She might also be wondering "How will I make myself understood and how will the "other" understand me?" We must remember that when Bikash executed this portrayal, Bengali society was still struggling to overcome the effects of the 1943 famine, as well as the Partition refugee settlement and social integration. The painter's marking of the old destitute woman's forehead with a reddish bindi, along with giving her pink lips, carry across something of a sarcastic air. The reddish plaintive glow in her eyes seems to express some expectation, maybe an answer from the social-mirror's authority. Abstraction shows the worst fate that can befall a human being. 
It is interesting to contrast this painting with Bikash's Shabari I (Mixed Media, 1989, Fig. 23), the woman with utterly black eyes, poor white sari, a white bindi, a Shabari possibly embodying a younger version of the character in the Ramayana. In this epic story, king Rama accepts berries from the hands of an untouchable tribal woman named Shabari. This representation may remind us of the Hindu reformers' agenda that focused, among other things, on the fight against untouchability and change for the condition of widows. Other critics, such as Manasij Majumder, interpreted Shabari, probably due to the dark beastly eyes, as an image of implicit female sexuality. However, the canvas plays with contrasts suggesting a multiplicity of interpretations, meanings and identities, starting from the title up to the depiction. There is no certainty about the finality of a particular reading or the specific meaning of any artistic work.

The woman in Abstraction embodies the utter naked self of poverty and stands as a symbol of the atrocities human societies are capable of. She seems herself to be the ghost of history, both a surplus and a lack in the structure of social architectonics, a most concrete embodiment of the anxiety of becoming and a stark reflection on a woman's fall from the graces of the social judges. To appreciate the full impact of the image, it might do to bring to mind Bakhtin's understanding of the act of contemplation and the "excess of seeing" through aesthetic activity. $\mathrm{He}$ writes that "the first step in aesthetic activity is my projecting myself into [the other]" so as to experience him or her from within them, but then $I$ must "return into myself." Such projecting of ourselves into another person and experiencing the suffering as their suffering marks precisely the point of "return" into ourselves and the beginning of "aesthetic activity proper," according to Bakhtin (Author and Hero in Aesthetic Activity, 22-26).

Something similar can be said to happen when we truly experience a painting or a literary text. As we project ourselves into the world of the canvas/text, only to "return" into ourselves with the "material" we experienced, this material eventually gets close to a "unitary, intuitable whole of meaning" ("Author and Hero" 25-26). Thus the process of deriving a unitary meaning of a given work of art is part of acquiring a larger consciousness, whereby the viewer/receiver may and must experience his/her body through the body of the other. When, however, the other body we mentally experience represents a radical opposite, the experience can be unsettling. That is perhaps why both the viewing and experiencing a painting like Abstraction or, in a different context, encountering homeless people in the streets - in our public space, as it were, that is the private 
space of those destitute souls - can constitute a psychologically disturbing experience, posing as it does certain threats to our overall idea about our-selves and our bodies. One way of dealing with this is to first become aware of the occurrence of the encounter and then to "answer" to the experience actively. As Bakhtin has put it "I have to answer with my own life for what I have experienced and understood in art, so that everything I have experienced and understood would not remain ineffectual in my life" ("Art and Answerability," 1). This idea leads to a responsible engagement with art, an active involvement with the artistic text, and the capacity of assuming responsibility for the connection between art and life. In the process, both the experience and the understanding of that experience become crucial.

The "answerability" of Bikash to the relation between art and life grows into a critique of society and its mores. As a case in point, consider his painting Pineapple (Mixed Media, 1987, Fig. 24) in which he criticizes the passivity and even non-identity of Indian women by satirizing a phallic symbol. Here, a plump faceless woman clad in a white sari holds in her arms two upright pineapples as a stand-in for her non-existent bust. Different perspectives of the woman as faceless, headless, or eyeless, seen in Bikash's visual accounts of The Office Girl (Oil, 1979, Fig. 25), Onlooker (Fig. 3) and others, all suggest uncertain identities and impotence in terms of agency.

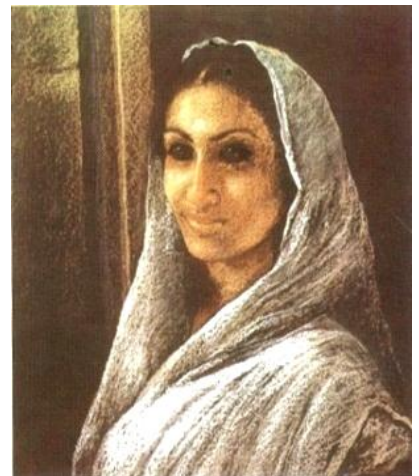

Fig. 23: Shabari I

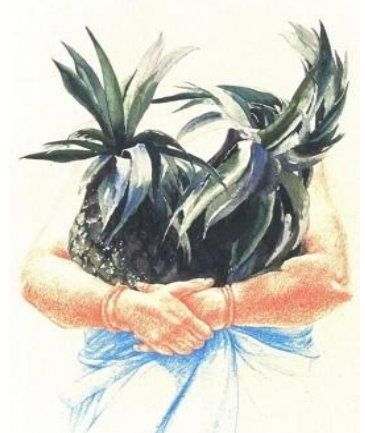

Fig. 24: Pineapple 


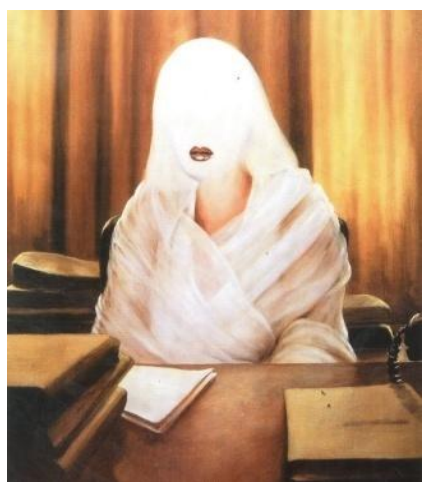

Fig. 25: Office Girl

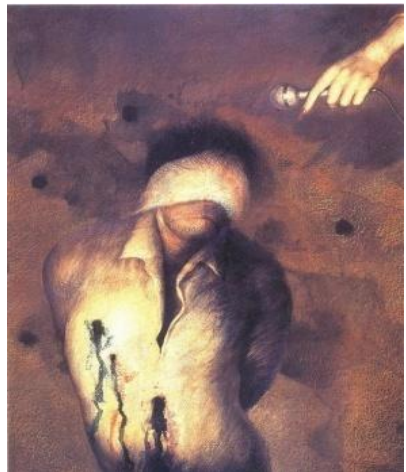

Fig. 26: Interview

Multiple debates about the place of woman in Indian society seem to culminate in the illustration of her versus him in the canvas entitled Interview (Bikash 1973). In this painting a wounded blindfolded man, his chest struck by three bullets, is being interviewed by a woman projected onto the canvas as an elegant hand with painted nails holding a microphone - a metonymic expression of collective women's consciousness questioning, interrogating rather, the patriarchal order itself and the exercise of power. In the visual rendition of Interview (Fig. 26) the muteness and blindness of the man is suggestive also of history's silence and a clash with the "voices" of (modern) women in news media, as well as of the history of violence.

\section{Woman in/as City and History}

In post-Independence India, the woman has often been associated with notions of urbanity and modernity both in literature and visual culture. The association of woman with the city has been particularly striking. In Bikash's painting She (Oil, 1968, Fig. 27), for example, the woman is explicitly made to govern the body and soul of the city, thus being both inside and outside (above) the city. In comparison, the woman in Sanatan Dinda's painting is depicted as an integral part of the city walls in Kallolini Tilottoma (Fig. 28) and Banalata (Fig. 29), where Kolkata takes the shape of a beautiful woman, a nude angelic corporeal self with vaguely visible wings. Both paintings, Banalata and Kallolini Tilottoma, are inspired by the famous poem "Banalata Sen" of Jibanananda Das, in which the poet expresses his hope that one day Kolkata would become a "beautiful, lively, effervescent city." What is remarkable in the photographic paintings of Dinda is the depth of vision, combined with an elegance of lines, a rendition of the poetry of city woven in the 
poetry of womanhood, along with multiple cultural symbols (e.g. flower garland, peacock feather etc.).

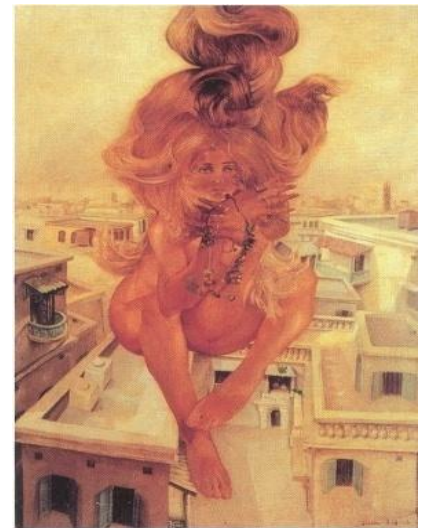

Fig. 27: Bikash, She (1968)

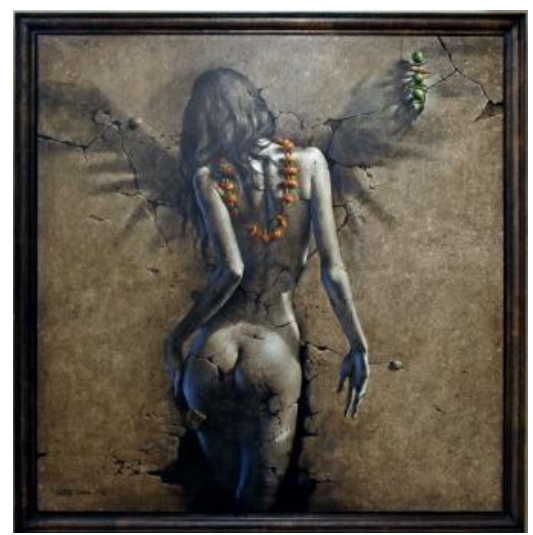

Fig. 28: Dinda, Kallolini Tilottoma

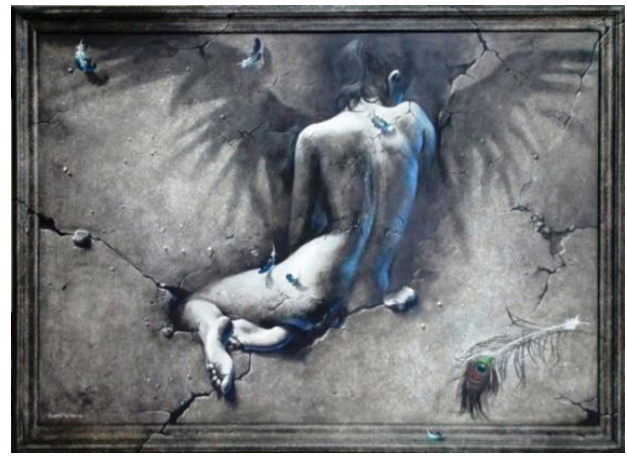

Fig. 29: Dinda, Banalata

The women in this series embody ideas of womanhood and history, being comparable in their uniqueness with the mysterious Banalata Sen of Jibanananda. The poem reveals itself as a canvas with fluid lines, conceptual associations and contrasts among which the light and shadows of individual histories play hideand-seek. It captures a Bakhtinian architectonics of a culture's psyche in a process of transformation. In Banalata Sen (1942), as Sisir Kumar Das observes, the "narratorial voice" gets connected with "the ever-moving forces of history" in "the haunting rhythm, rich imagery, the magic of proper names and the ethereal beauty of the concluding sestet" (Das 2002, ix). The verses brushed by Jibanananda reveal mystery, while the fluidity of identities is put forward by the flowing lines on the book cover sketched by Satyajit Ray (Fig. 30). Arpita Singh's Banalata Sen (Fig. 31) is an example of "answerability" and "authorship" as an exegesis that 
puts Jibanananda's text into a new embodiment and draws upon a notion of multiple narratives within a single visual text. When engaging in the viewing/reading of Banalata Sen, we actually engage in a reading of memories that move within the collective cultural architectonics; we exercise a nostalgia and an experience where the reading - like the artist's act of creation- "bears the guilt for the vulgar prose of life"; as Bakhtin emphasizes, "art and life are not one, but they must become united in myself - in the unity of my answerability" ("Art and Answerability" 2). Thus the viewer-reader (or view-reader) needs to continuously adjust his/her worldview paradigm so as to incorporate this "prose of life" that recounts itself in any new experience, so that the "excess of seeing" and the "return into the self" may unfold easily and constructively.

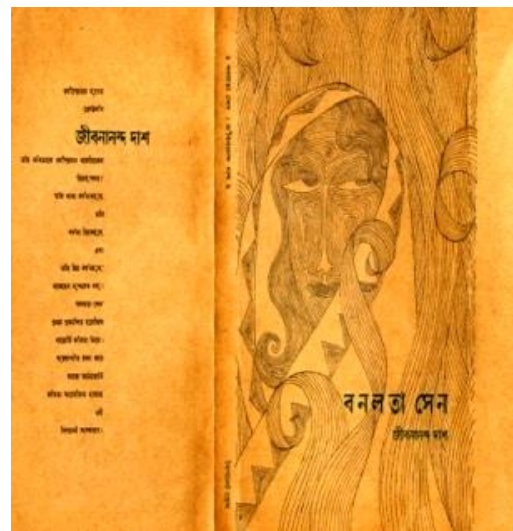

Fig. 30: Ray's Banalata Sen

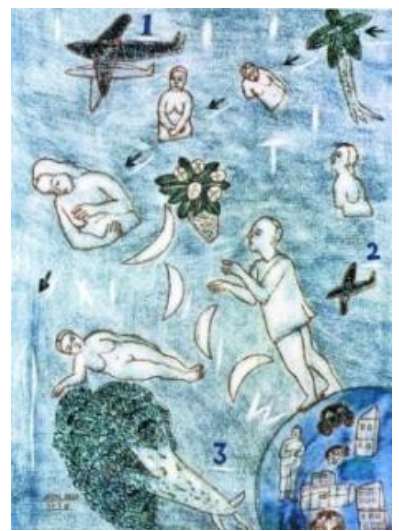

Fig. 31: Singh, Banalata Sen

The "vulgar prose of life" informed Jibanananda's poem itself: it is most likely that he came to write the poem after seeing the name of Banalata Sen on the list of political prisoners under the British rule published in the Ananda Bājār Patrikā around 1932. She was imprisoned at Rajshahi Jail, close to a place named Natore, which figures in the poem. Later, after she was released, it is remarkable to think that the poet looked for her and it seems they even met (A. Mitra 2010, 4). Banalata Sen, as an embodiment, stands for a "unique slice of time/space"- the "instrument for assigning specific value to abstract time and space" (Bakhtin 1990, 18-19). She signifies a respite within the wholeness of time along the avenues of which the poet takes his lonely contemplative walk like a flâneur. Jibananada contemplates the lady as an embodied mystery through which he himself seems to look for a personal history within the collective history. Interestingly, this idea of a 
collective history is powerfully rendered in one painting from Arpana Caur's series entitled Body is just a Garment (e.g. Fig.32, Oil on canvas, 2004).

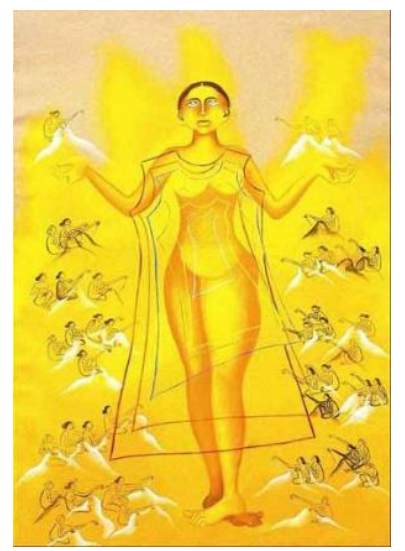

Fig. 32: Caur, Body is Just a Garment

Deeply philosophical in its content, Arpana Caur's painting foregrounds the notion of unity in diversity, in which the woman-represented by the sketched garments in multiple layers as well as by the many women (maybe tailors of histories) strewn around the central being in the canvas-is the weaver of the world, the supporter of creation and the epithet of identity as one and many at the same time. The woman in Body is Just a Garment attempts to hide a mystery akin to that of Banalata Sen; though seemingly relaxed, her body language reveals at a close reading that she is holding a secret: her feet are crossed, her eyes vacant and veiled by a tinge of sadness. Such illustrations confirm that Indian women artists like Arpana Caur, Arpita Singh, Amrita Sher-Gil and few others manifested strong voices and visual idioms featuring unique styles.

Throughout history, as Amartya Sen noted, women have often been mere "passive recipients" of welfare projects, sometimes they were "promoters of social change," and more recently they have become "agents" in the struggle for women's rights. Be that as it may, women across the board still need to struggle far more than men in order to succeed in their careers and to assert a new position for themselves in society. Sen calls for an "urgent social understanding" of gender inequality and "a fuller cognizance of the power and reach of women's enlightenment and constructive agency and an adequate appreciation of the fact that women's power and initiative can uplift the lives of all human beings" (Sen $2005,249-50$ ). I believe that such understanding can be entailed only by an 
undertaking of responsibility and "answerability" for our own attitudes towards the people we interact with, as well as towards the social forces that surround and dictate the dynamics of such interactions. These forces extensively guide and shape all inter-personal relationships as well as all relations and dialogism between us and the objects (including art forms and literature) that we come across. This social dynamics in the real lived chronotope is replicated with its parameters in the virtual world, where issues such as gender, community or nation do not seem to be any less relevant.

\section{Virtual Womanhood and Cyberfeminism}

With regard to virtual art, Cornelia Sollfrank's experiment- "Female Extension" (1997), an illustrious instance of cyberfeminism, proved that in net competitions female artists are still discriminated against on the grounds of gender. According to Kate Southworth, Female Extension is an "interrogation of the technology that produces it. Sollfrank foregrounds processes of making art in a network context, emphasizing the ways in which such processes are structured by the materiality of the Internet" (2009). She created 200 female artists, simulations with complete virtual identities and artistic works, all generated by a machine, and enrolled them in the net competition "Extension," where surprisingly, the winners were three men artists. Such discriminations are easier to handle in the virtual world, where one can simply switch from one identity to another.

With the emergence of virtual communities and on-line communication, new concepts of womanhood have emerged, premised on the possibility of actually creating virtual people, dating them and even engaging in "virtual infidelities," these topics largely being debated in the West. In America there have so far been a few cases of actual divorces requested by wives for being cheated on by husbands with virtual women on-line, posing great difficulty for legislation lacking a legal framework for such complaints. Similarly, the virtual existence in "Second Life" has been proved to cause addiction in players leading to psychological disturbances in their real life. The internet world has over time come to signify an escape from the real concrete world into a realm where each individual can become a sort of god exercising one's authority, power and imaginative skills to create a world to one's liking. The virtual world becomes a dimension where the player has the illusion of being responsible for one's acts, while in real life the same individual lacks the ability to take actual action and "answer" for their acts. 
The net-world offers the possibility of constantly changing identities so as to embody a person whose gender, physical and other features are different to that of the "real" individual. Researchers put forward in a survey that gender swapping in on-line socialization is more frequent amongst women than men, the main reason being a lesser possibility of being harassed as a male. The same survey noted that men who switched gender in multi-user games, apparently did so because in their view virtual women were treated better (Hussain and Griffiths 2011, 47-53). Such research cannot be entirely conclusive on the matter, but it does enable us to ask new questions in relation to womanhood and women's attitudes towards their femaleness in real and virtual lives. Similarly, many queries may be made about the exclusion of other forms of femaleness (for instance those experienced by the queer and transsexual communities) from the purview of such surveys. An investigation of virtual communities, the roles played by their members, the interaction between men and women as well as other gender groups in cyberspace and cybertime would give a clear image about virtual world socialization in relation to real life attitudes and expectations.

In the Indian context, virtual socializing is a ubiquitous phenomenon. It is present all over the country. The distinctions between traditional and modern notions of womanhood are not as strongly emphasized in the virtual world mainly because most, if not all, internet users allegedly fall into the modern citizen category. Although this may be the case in general, Indian matrimonial sites, through which many arranged marriages are concretized in real life, clearly operate within the traditional/modern paradigm of identities. Thus, in order to better sell their products and services to their customers, these sites chiefly distinguish identities (of the human products) in terms of caste, religion, gender, ethnic community, class, mother tongue, profession and other criteria. This would suggest that it is precisely the requirements advanced by real-life individualscustomers of such matrimonial services - that reinforce such distinctions, while projecting them from society into virtual space. At present in India there are more than 75 million internet users, mostly young and mostly male, but female surfers are more inclined towards the socializing sites and IM ("Digital Reality in India"). The rapport of users vs. non-users of the virtual world and online games/surfing in Indian society must be understood along with its relations and effects on real life for a better understanding of the direction and impact virtual existence may take in the long run. 
There have been many cases of virtual harassment that started online and were then pursued further offline by aggressors, generally categorized as obsessive, delusional or vengeful cyber stalkers ("Cybercrime in India" and "ViziSense report on Women Behavior"). The problem is that in many cases, both in virtual and real life, harassment is not reported by Indian women out of fear or embarrassment, thus encouraging the aggressors to continue their attacks. Further research is necessary to understand all the implications and effects of netsocializing between men and women in India, upon society itself and upon the psyche of the users.

\section{Concluding Remarks}

As discussed throughout this paper, several Indian artists have registered and criticized in their literary and visual forms of art the issues faced by women related to their condition within society, the discrimination and disrespect they face. But many further questions lend themselves for even more investigation: What factors could enable an architectonics of womanhood that would include all types of women, both from within and from outside the social scheme? Can we think of possible ways of inclusion and then integration of homeless, untouchable and disabled women within the Indian feminist and social agendas? How can we understand the evolving identities and selves of such women? For as long as women are seen to be objects of the patriarchal gaze, can violence and abuse against them be avoided? Bakhtin has powerfully suggested that one's "excess of seeing" is the other's lack and vice versa, and in order to overcome the mutual lack the two must share their excess. With this point in mind can we begin to anticipate an exchange between the street dwellers and the "citizens" belonging to the respectability scheme?

The artists I have discussed have depicted diverse notions of womanhood and in their unique artistic discourses they have strongly advocated issues of women's emancipation. In turn they have engaged the reader and viewer to broaden their vision so as to better understand the issues at hand. All forms of art and their dissemination into both real and virtual worlds entail a necessity for conscious (re)action towards - and reliable response to - the social concerns raised by the arts. In this sense, I would like to propose an exercise of reading-viewing an artistic work, be it literary or visual, through the prism of interactions/intersections between the concepts of self, art and answerability as suggested by Bakhtin, 
keeping in mind both the emotional-aesthetic experience as well as the necessity for an active social-cognitive transformation within the cultural psyche itself.

Note: The copyright for the images employed in this paper belongs to the artists. Except the photos taken at various art exhibitions, the other images have the following sources:

- Bikash Bhattacharjee's paintings, courtesy: Niyogi Books New Delhi.

- M.F. Husain's Mother Teresa painting, courtesy Spear Art Museum. Web. Accessed August 27, 2012. <http://www.cyberadsstudio.com/SPEAR/hussain/tour22.htm>.

- Subrata Gangopadhyay's painting Mother (2008), courtesy My Indian Art. Accessed August, 27, 2012. $<\mathrm{http}: / /$ www.myindianart.com/artistname.php?page=2\&artid=36>.

- Arpana Caur's painting Body is just a Garment, by courtesy of the artist.

- Sanatan Dinda's Kallolini Tilottoma, exhibited at The $44^{\text {th }}$ Annual Exhibition, Birla Academy of Art and Culture, Kolkata. Archived Exhibition catalogue online. Accessed August 27, 2012.

$<$ http://www.birlaart.com/viewexhibition.php?exhid=56\&pageno=15>.

- Sanatan Dinda's Banalata, courtesy Indian Master Painters. Accessed August 27, 2012. <http://auctions.indianmasterpainters.com/artdetails.asp?id=56>.

- $\quad$ Sudip Roy's paintings, the artist's exhibition/ website. <http://www.sudiproy.com>.

\section{References}

Bakhtin, Mikhail. 1990 (1924). Art and Answerability. Early Philosophical Essays by Mikhail M. Bakhtin, edited by Michael Holquist and Vadim Liapunov. Austin: University of Texas Press.

"Cybercrime in India." Accessed March 15, 2012. http://www.indianchild.com/cyberstalking.htm.

Dalmia, Yashodhara. 2001. "A Passion for the Human Figure.” The Making of Modern Indian Art. The Progressives. Delhi: OUP.

Das, Sisir Kumar. 2002. "Introduction." In A Certain Sense. Poems by Jibananada Das. 2nd ed., edited by Sukanta Chaudhuri, i-xv. Kolkata: Sahitya Akademi.

"Digital Reality in India." www.magazinetraining.com. Accessed March 15, 2012. http://www.magazinetraining.com/Assets/Docs/PDF/2011\%20Conferences/Digital\%2 0Reality\%20in\%20India.pdf.

"E-Mail, Search and Social Networking Top the Charts for Indian Women." Accessed March 15, 2012. http://www.vizisense.com/html/press/ol_womenBehav26Jul10.html.

Ghai, Anita. 2009. "Disabled Women: An Excluded agenda of Indian Feminism." In Disability and Society. A Reader, edited by Renu Addlakha et al., 411-31. New Delhi: Orient BlackSwan.

Hussain, Zaheer, and Mark D. Griffiths. "Gender Swapping and Socializing in Cyberspace: An Exploratory Study." CyberPsychology \& Behavior February 1, 2008, 11(1): 47-53. Accessed 24 February. 2011. doi:10.1089/cpb.2007.0020. 
Majumder, Manasij. 2007. Close to Events. Works of Bikash Bhattacharjee. New Delhi: Niyogi Books.

Mitra, Ashok. 2010. "Rajshahi Jele Bondi Chhilen Ek Banalata Sen” (A Banalata Sen was imprisoned at Rajshahi Jail, 4). Ananda Bajār Patrikā, December 21.

Mitra, Premendra. 2010. "Juthika." In The Oxford India Anthology of Bengali Literature, Vol. II (1941-1991), edited by Kalpana Bardhan, 117-24. Delhi: OUP.

Peeren, Esther. 2008. Intersubjectivities and Popular Culture. Bakhtin and Beyond. California: Stanford University Press.

Sen, Amartya. 2005. "Women and Men." In The Argumentative Indian. Writings on Indian Culture, History and Identity, 220-50. London: Penguin Books.

Sollfrank, Cornelia. 1997. FEMALE EXTENSION. Accessed April 10, 2011. http://www.artwarez.org/femext/content/femext.html.

Southworth, Kate. 2009. Cornelia Sollfrank: FEMALE EXTENSION (1997). Accessed November 22, 2012.

http://texts.gloriousninth.net/sollfrank/FEMALE_EXTENSION.pdf.

Tagore, Rabindranath. 2000(1941). "The tale of a Muslim Woman” (Musalmanir Galpa, 1941). Image and Representation. Stories of Muslim Lives in Indin, edited by Mushurul Hasan \& M. Asaduddin. Delhi: OUP.

Varadarajan, Mu. 1988. A History of Tamil Literature. Translated by E. S. Viswanathan. New Delhi: Sahitya Akademi. 